\title{
Interaction of Extracellular Histones with DNA and Actin Filaments
}

\author{
Edna Blotnick-Rubin ${ }^{1, ~ *, ~ A n d r a s ~ M u h l r a d ~}{ }^{2}$ \\ ${ }^{1}$ Department of Medical Neurobiology, Institute for Medical Research Israel-Canada, Hebrew University of Jerusalem, Jerusalem, Israel \\ ${ }^{2}$ Institute of Dental Sciences, Hebrew University-Hadassah School of Dental Medicine, Jerusalem, Israel
}

Email address:

ednab@ekmd.huji.ac.il (E. Blotnick-Rubin)

${ }^{*}$ Corresponding author

\section{To cite this article:}

Edna Blotnick-Rubin, Andras Muhlrad. Interaction of Extracellular Histones with DNA and Actin Filaments. Advances in Biochemistry. Vol. 8, No. 2, 2020, pp. 26-37. doi: 10.11648/j.ab.20200802.11

Received: March 26, 2020; Accepted: April 13, 2020; Published: May 14, 2020

\begin{abstract}
Histones are located in the cell nucleus. They are positively charged small proteins which became extracellular upon apoptosis, necrosis, and infection - induced cell death. The mixture of extracellular Histones was shown to bundle Actin filaments and digested by bacterial proteases, which was inhibited by DNA and Actin. Here we studied the interaction of five major family of Histones, H2A, H2B, H3.1, H1 and H4, with DNA and Actin filaments. We found that all the Histones studied bound to DNA, increased the viscosity of Actin containing solutions and bundled Actin filaments in various degrees. The bundling of Actin filaments by Histones was inhibited by DNA, NaCl and DNase1. DNA and Actin filaments also inhibited the proteolysis of the five Histones by Subtilisin, Fusolisin and Pseudomonas Aeruginosa bacterial proteases. Both the degree of the proteolysis and its inhibition was different with various Histones. The results indicate that all the Histones studied bind strongly to the negatively charged DNA and to the Actin filaments.
\end{abstract}

Keywords: H1, H2A, H2B, H3.1, H5 Histones, F-actin Bundling, Histones Binding to DNA, Effect of DNA and F-actin on Proteolysis

\section{Introduction}

Histones are highly positively charged small proteins located in the cell nucleus of eukaryotes spooled around DNA. H2A, H2B, H3.1, $\mathrm{H} 1$ and $\mathrm{H} 4$ are the major family of histones. $\mathrm{H} 2 \mathrm{~A}, \mathrm{H} 2 \mathrm{~B}, \mathrm{H} 3$, and $\mathrm{H} 4$ are core histones, histone $\mathrm{H} 1$ is linker histone. Core histones are dimers, they have a histone fold domain: three alpha helices linked by two loops. $\mathrm{H} 1, \mathrm{H} 2 \mathrm{~A}$, and $\mathrm{H} 2 \mathrm{~B}$ histones are rich in lysine and $\mathrm{H} 3$ and $\mathrm{H} 4$ are rich in arginine [1] Histones are separated from DNA and released from the cell and became extracellular as a consequence of apoptosis $[2,3]$ necrosis [3] and infection - induced cell death [5]. H2A [6] H2B [7] H4 [8] and H1 [9] extracellular histones have antimicrobial activity $[10,11]$. We showed that the high antimicrobial activity of histone mixture is inhibited by the negatively charged DNA and F-actin filaments [12]. DNA and F-actin protect the degradation of histones by Pseudomonas aeruginosa and Porphyromonas gingivalis proteases [12]. Extracellular histones have a bad side too, they act as inflammatory agents [13], major mediators of death in sepsis [13] and have a significant role in tissue injury and inflammation [5]. We showed that histone mixture $\mathrm{H} 3$ (histone type III) and H2A histone bundle Factin, increase the viscosity of the F-actin containing solutions and polymerize G-actin [14]. The histone mixture-actin bundles are dissociated by DNA and 300$400 \mathrm{mM} \mathrm{NaCl}$ [14]. The histone-actin bundles are highly stable. They have pathophysiological significance since they contribute the formation of the high viscosity sputum in cystic fibrosis [15].

In this work we studied the binding of $\mathrm{H} 2 \mathrm{~A}, \mathrm{H} 2 \mathrm{~B}, \mathrm{H} 3.1$, $\mathrm{H} 1$, and $\mathrm{H} 2$ extracellular histones to DNA and F-actin. The bundling of actin filament by these histones and their effect on the viscosity of F-actin containing solutions was investigated. We also studied the effect of DNA, DNase1 and ionic strength on the histone bundling of actin filaments. The digestion of these histones by subtilisin, Pseudomonas aeruginosa and fusolisin bacterial proteases 
and the effect of DNA and actin on the proteolysis were also investigated.

\section{Materials and Methods}

\subsection{Materials}

ATP, ADP, dithiothreitol (DTT), thiazole orange, DNase1, and deoxyribonucleic acid (DNA) from calf thymus were purchased from Sigma Chemical Co. (St Louis, MO). Muscle acetone dry powder was purchased from Pel-freeze Biologicals (Rogers, AR). Human recombinant H2A, H2B, $\mathrm{H} 3.1, \mathrm{H} 1$ and $\mathrm{H} 4$ histones were bought from New England Bio Labs (Ipswich, MS). Viscous Aqua was purchased from Ursa BioScience (Abingdon, MD).

\subsection{Preparation of Actin}

CaATP-G-actin was prepared from acetone dried powder derived from the back and leg muscles of rabbit by the method of Spudich JA, and Watt S [16] that yields highly homogeneous actin in purity greater than $90 \%$. CaATP-Gactin was stored in a buffer containing $5 \mathrm{mM}$ TrisHCl, 0.2 $\mathrm{mM} \mathrm{CaCl} 2,0.2 \mathrm{mM}$ ATP, $0.5 \mathrm{mM} \beta$-mercaptoethanol, $\mathrm{pH}$ 8.0 (CaATP-G-buffer). MgF-actin was polymerized from CaATP-G-actin by incubation with $2 \mathrm{mM} \mathrm{MgCl}_{2}$ at room temperature for $30 \mathrm{~min}$. $\mathrm{MgF}$-actin was diluted for further treatments in MgF-buffer containing $5 \mathrm{mM}$ MOPS, $2 \mathrm{mM}$ $\mathrm{MgCl}_{2}, 0.2 \mathrm{mM}$ ATP and $0.5 \mathrm{mM}$ DTT, pH 7.4. The concentration of rabbit skeletal muscle CaATP-G-actin and $\mathrm{Mg}-\mathrm{F}$-actin was determined spectrophotometrically using the extinction coefficients $E 1 \% 290 \mathrm{~nm}=11.5 \mathrm{~cm}-1$. (The optical density of actin was measured in the presence of $0.5 \mathrm{M} \mathrm{NaOH}$, which shifts the maximum of absorbance from $280 \mathrm{~nm}$ to $290 \mathrm{~nm}$ ). Molecular masses of skeletal actin assumed to be $42 \mathrm{kDa}$, and those of H2A, H2B, H3.1, H1 and $\mathrm{H} 4$ histones assumed to be 14.1, 13.7, 15.4, 20.8, and $11.2 \mathrm{kDa}$, respectively.

\subsection{Actin Viscosity and Bundling Measurements}

The histones induced viscosity increase of F-actin was measured by Viscous Aqua fluorescent viscosity probe (Ursa BioScience, Abingdon, MD). The fluorescence of the probe was measured in a PTI spectrofluorometer at $400 \mathrm{~nm}$ excitation and $440 \pm 540 \mathrm{~nm}$ emission wavelengths and at 492 $\mathrm{nm}$ emission maximum. The fluorescence of the probe is increasing with the increase in viscosity.

The extent of the histones caused F-actin bundling and the effect of DNA, DNasel and $\mathrm{NaCl}$ (ionic strength) on the bundling was studied by low speed centrifugation and SDSPAGE (Poly Acrylamide Gel Electrophoresis). The samples were centrifuged at $20,800 \mathrm{xg}$ for $8 \mathrm{~min}$. This low speed centrifugation sediments bundled actin but leaves unbundled actin in the supernatant. The supernatants were run on SDSPAGE and analyzed by densitometry with TINA $2.07 \mathrm{~d}$ software.

\subsection{Proteolytic Digestion and Densitometry}

Histones, $3 \mathrm{uM}$, were digested by $2.5 \mathrm{ug} / \mathrm{ml}$ subtilisin, by $100 \mathrm{x}$ diluted $P$. aeruginosa supernatant and by $8 \mathrm{ug} / \mathrm{ml}$ fusolisin (17), respectively. Samples digested also in the presence or absence of $8 \mathrm{ug} / \mathrm{ml} \mathrm{F-actin} \mathrm{or} 50 \mathrm{ug} / \mathrm{ml}$ DNA, respectively to check their effect on histone proteolysis. All constituents were added simultaneously, run on $12 \%$ SDSPAGE, visualized by Coomassie Blue and evaluated by densitometry with TINA $2.07 \mathrm{~d}$ software.

\subsection{Binding of Histones to DNA}

The binding of histones to DNA was measured by fluorescence intercalator displacement (FID) assay [18, 19]. Briefly, a quartz cuvette was loaded with thiazole orange $(0.55 \mu \mathrm{M})$ in STE buffer $(10 \mathrm{mM}$ TrisHCl, $50 \mathrm{mM} \mathrm{NaCl}, 1$ mM EDTA, $\mathrm{pH} 8.0$ ). The fluorescence of this solution was measured (excitation $509 \mathrm{~nm}$, emission $527 \mathrm{~nm}$ ) and normalized to $0 \%$ relative fluorescence. DNA in STE buffer was added to the cuvette $(5 \mu \mathrm{g} / \mathrm{ml}$ final concentrations $)$. After equilibrating for $5 \mathrm{~min}$, the fluorescence of this solution was recorded and normalized to $100 \%$ relative fluorescence. Histone solution was added after the DNA addition, which decreases fluorescence, since histones binding to DNA removes it from thiazole orange. Fluorescence decrease was recorded after $5 \mathrm{~min}$ incubation with histones. The percent decrease of fluorescence is a measure of binding of histones to DNA.

\subsection{Statistical Analysis}

Student's t test and one-way ANOVA were used for calculations of $\mathrm{p}$ values to evaluate the significance. $*=$ $\mathrm{p}<0.05, * *=\mathrm{p}<0.01, * * *=\mathrm{p}<0.005$. Unless specified, all presented data are the means of three independent experiments performed in triplicate. All presented SDS gels blots are representative of three independent experiments.

\section{Results}

\subsection{Binding of Histones by DNA}

The binding of the five extracellular histones to DNA was studied by thiazole orange displacement assay (Materials and Methods). All these histones were found to bind to DNA (Figure 1). The binding was measured by two methods: 1, by decrease of thiazole orange fluorescence upon addition of a constant concentration of histone (Figure 1A) and 2, by determination of the concentration of histone needed for $50 \%$ decrease of fluorescence (Figure 1B). The binding of $\mathrm{H} 1$ and $\mathrm{H} 2 \mathrm{~A}$ histones were significantly stronger to DNA than the other three ones according to the results obtained by the two methods. Among H3.1, H2B and H4 histones the binding of H3.1 was a little, but not significantly stronger than those of $\mathrm{H} 2 \mathrm{~B}$ and $\mathrm{H} 4$ histones. 


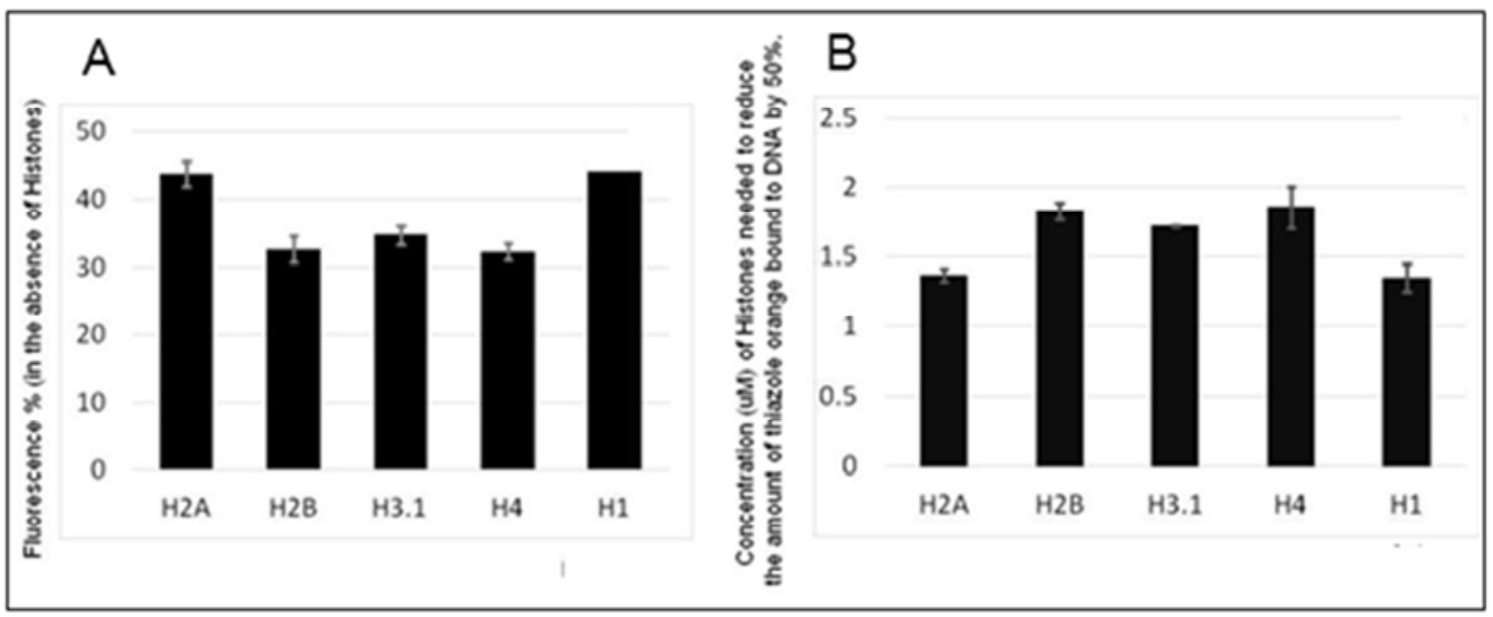

Figure 1. Histone binding to DNA measured by the thiazole orange fluorescent intercalator displacement assay. $1.2 \mu M$ histones were added to $0.55 \mu M$ thiazole orange in STE buffer containing $2.5 \mu \mathrm{g} / \mathrm{ml}$ DNA. Fluorescence was measured as described in the Materials and Methods. The data presented represent the mean and standard deviation of three independent experiments. (A), Effect of $1.2 \mathrm{uM}$ histone on the thiazole orange fluorescence of $2.5 \mathrm{gug} / \mathrm{ml}$ $D N A$. (B), Concentration of histones needed to reduce the amount of thiazole orange bound to DNA by $50 \%$. ( $p<0.05$ for $1 \mathrm{~A}$ and $p<0.1$ for $1 B$ )

\subsection{Histones Induced Viscosity Increase and Bundling of Actin Filaments}

F-actin filaments are negatively charged polyanions which react with positively charged polycations $[20,21]$. We found that the polycationic histones, as $\mathrm{H} 2 \mathrm{~A}$ histone and histone mixture interact with the negatively charged $\mathrm{F}$-actin, which is manifested in viscosity increase of F-actin containing solutions and bundling of F-actin filaments [14]. Here we studied the interaction of 5 extracellular histones with actin filaments by measuring the effect of these histones on the viscosity of F-actin containing solution and on the bundling of F-actin filaments.

The histones induced viscosity increase of F-actin was measured by Viscous Aqua fluorescent viscosity probe as described in the Materials and Methods.

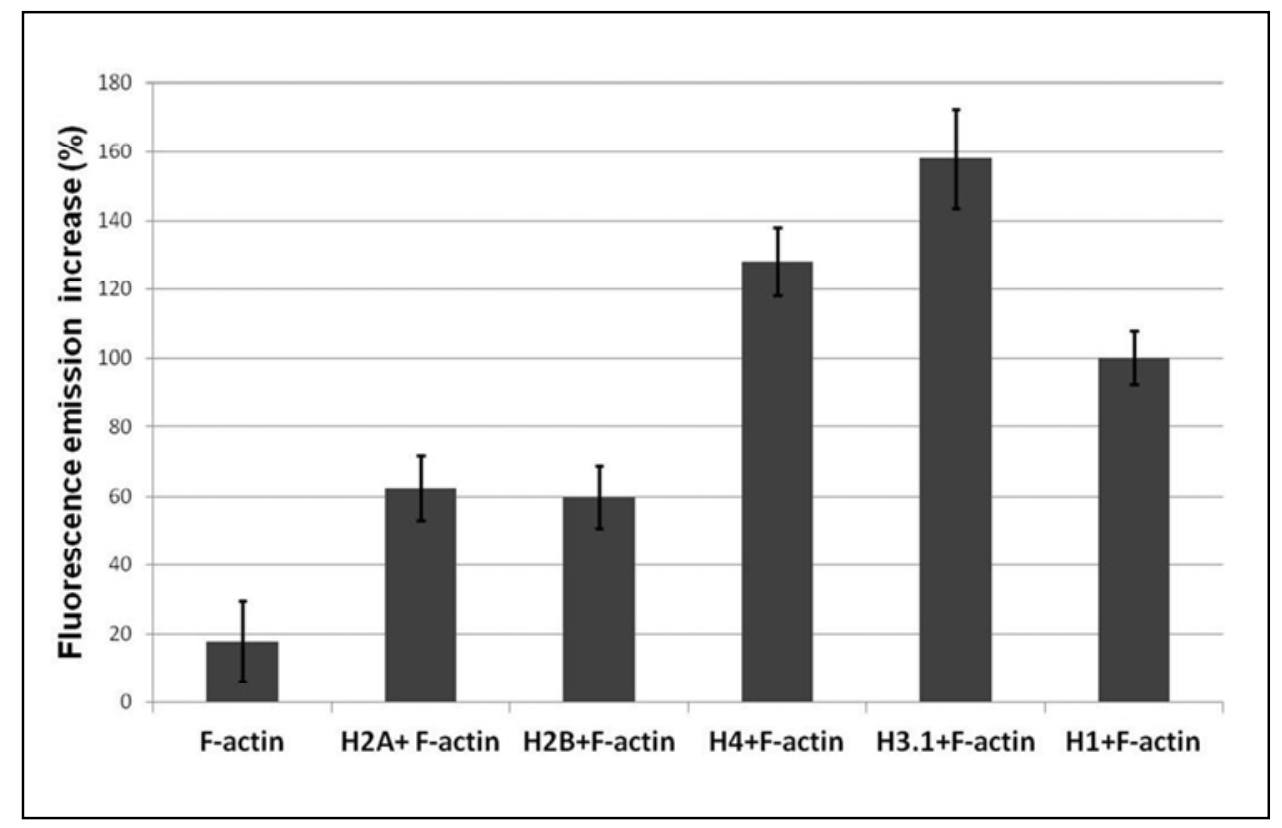

Figure 2. Histone increases the viscosity of F-actin containing solutions. Viscous Aqua in Ursa BioScience vial, was dissolved in $50 \mu$ l methanol, stock solution. To $4 \mu \mathrm{l}$ stock solution $62.6 \mu \mathrm{l} F$-actin buffer was added, this was the working solution. The reaction mixture, $150 \mu l$, contained $1.1 \mu \mathrm{M} F$-actin, $5 \mu \mathrm{l}$ Viscous aqua working solution in F-actin buffer and $3.0 \mu \mathrm{M}$ histone when added. The fluorescence of the reaction mixture was measured at $492 \mathrm{~nm}$ emission maximum as described in Materials and Methods. The histone induced fluorescence increase was calculated as: (F-actin+histone)-buffer fluorescence]/ buffer fluorescence) $x 100$. The fluorescence emission increases with the increasing viscosity of the samples. The data presented represent the mean and standard deviation of at least three independent experiments. $(p<0.005)$

All extracellular histones studied significantly increased the viscosity of F-actin containing solutions. The largest viscosity increase was observed with $\mathrm{H} 3.1$ histones and decreased in the order $\mathrm{H} 3.1>\mathrm{H} 4>\mathrm{H} 1>\mathrm{H} 2 \mathrm{~A}>\mathrm{H} 2 \mathrm{~B}$. The differences between $\mathrm{H} 3.1$ and rest of histones and between $\mathrm{H} 4, \mathrm{H} 1$ in one hand and $\mathrm{H} 2 \mathrm{~A}$ and $\mathrm{H} 2 \mathrm{~B}$ on the other hand 
were significant. The size of the viscosity increase is an indication of the binding strength between the various histones and the actin filaments.

F-actin bundles upon addition of polyvalent cations [20] because the repulsion between the negatively charged actin filaments is eliminated by the positive charged polycations [21]. The histones induced F-actin bundling was studied by low speed centrifugation since bundled actin filaments are sedimented at low speed while unbundled actin filaments sedimented only at high speed centrifugation.

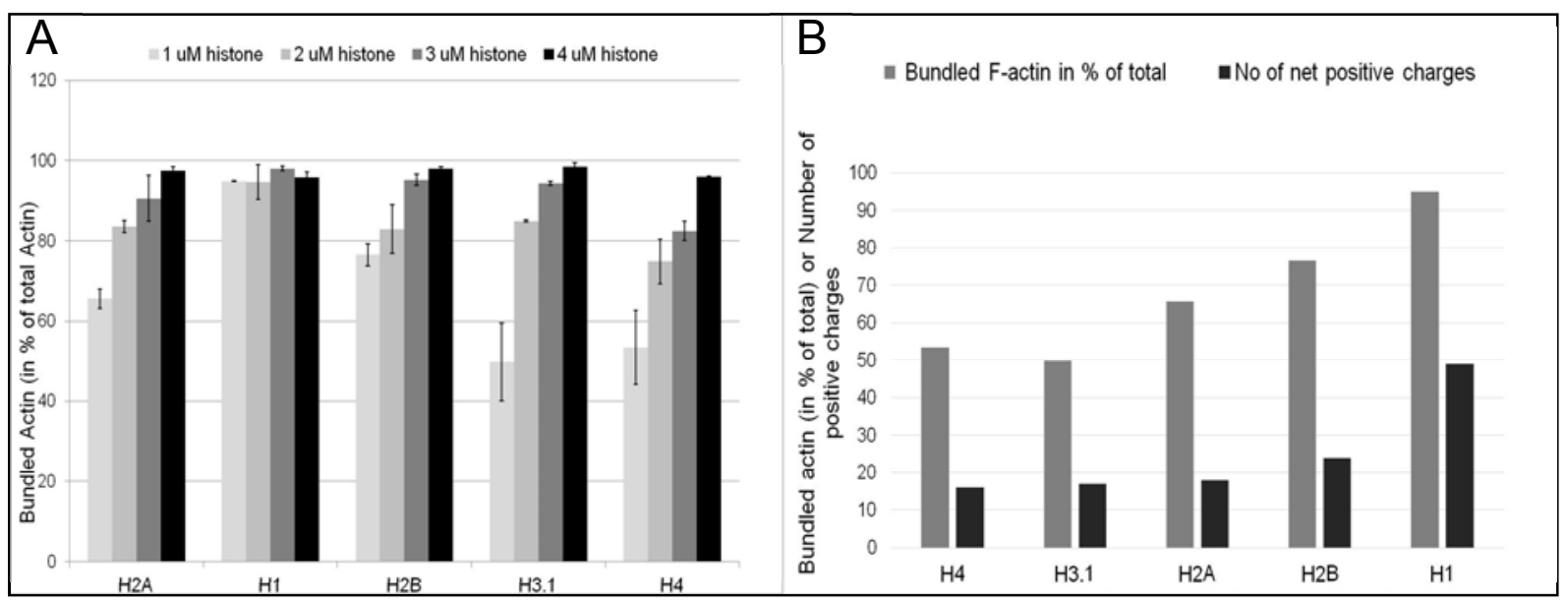

Figure 3. Histone induced bundle formation of F-actin followed by low speed centrifugation. (A), 1-4 $\mu M$ histones were added to $4 \mu M$ F-actin. The bundled $F$-actin was separated from the unbundled actin by low speed centrifugation and evaluated by SDS-Page as described in Materials and Methods. The presented data are mean and standard deviation of three independent experiments. (B), Correlation between percent of F-actin bundled by $1 \mu M$ histones and the net positive charge of the histones. $(p<0.1$ for $3 \mathrm{~A}$ and $p<0.01$ for $3 B$ ).

Histones are very efficient bundling agents of F-actin as was shown in our earlier study on mixture of histones [14]. All histones studied efficiently (in 53-95\%) bundled $4 \mu \mathrm{M}$ Factin already in substoichiometric $1 \mu \mathrm{M}$ concentration (Figure 3 ). The extent of $\mathrm{F}$-actin bundling caused by $1 \mu \mathrm{M}$ histones decreased in the order $\mathrm{H} 1>\mathrm{H} 2 \mathrm{~B}>\mathrm{H} 2 \mathrm{~A}>\mathrm{H} 4>\mathrm{H} 3.1$. The extent of bundling increased with the increasing concentration of histones added. All histones in $4 \mu \mathrm{M}$ or $3.5 \mu \mathrm{M}$ concentrations practically completely bundled $4 \mu \mathrm{M}$ F-actin (Figures 3A, 4, 5, 6). It is Important to note that there is a good correlation between the percentage of F-actin bundled by $1 \mu \mathrm{M}$ histones and the number of net positive charges contained in histones (Table 1), with the exception of H3.1 histone (Figure 3B). The results indicate that the electrostatic interactions between the highly positively charged histones and the negatively charged $\mathrm{F}$-actin has a definitive major role in the bundling of F-actin.

Table 1. M. W. and net positive charges of histones.

\begin{tabular}{lll}
\hline Histones & Molecular weight & Net positive charges \\
\hline H4 & 11236 & 23 \\
H2B & 13789 & 34 \\
H2A & 14000 & 27 \\
H3.1 & 15273 & 28 \\
H1 & 20732 & 56 \\
\hline
\end{tabular}

\subsection{Effect of Ionic Strength, DNA and DNase1 on the Histone Bundled Actin Filaments}

Ionic strength increase has been shown to reverse the bundling of actin filaments induced by various polycations $[12,21]$ Polycation induced F-actin bundles are sensitive to ionic strength and unbundle (dissociate) with increase in the concentration of monovalent cations such as $\mathrm{NaCl}$ since they mask the electrostatic interactions between the polycations and the negatively charged actin filaments [20, 22]. The $\mathrm{NaCl}$ concentration needed to dissociate bundled F-actin filaments depends both on the strength of the hydrophobic and electrostatic interactions between F-actin and the polycation used for the bundling.

The extent of F-actin unbundling caused by $100 \mathrm{mM} \mathrm{NaCl}$ was between 5-19 percent with the various histones. The increase of $\mathrm{NaCl}$ concentration to $200 \mathrm{mM}$ increased the extent of unbundling with 2-5 percent, except in the case of $\mathrm{H} 2 \mathrm{~A}$ histone where the unbundling increased by 25 percent relative to that caused by $100 \mathrm{mM} \mathrm{NaCl}$. Addition of 300 $\mathrm{mM} \mathrm{NaCl}$ caused almost complete unbundling with the $\mathrm{H} 2 \mathrm{~A}$ and $\mathrm{H} 2 \mathrm{~B}$ histones while with the other three histones the unbundling increased only by $2-8$ percent relatively to the extent observed by $200 \mathrm{mM} \mathrm{NaCl}$. With H3.1, H1 and H4 histones small unbundling increase was obtained even when the $\mathrm{NaCl}$ concentration further increased from $300 \mathrm{mM}$ to $400 \mathrm{mM}$. Histone bundled F-actin is relatively insensitive to increase of ionic strength since unbundling caused by 100 $\mathrm{mM} \mathrm{NaCl}$ was 5-19 percent depending on histone used, while other polycations, such as polylysine, spermine and lysozyme [21] and histatin [23] bundled F-actin, already completely disassembled upon addition of $100 \mathrm{mM} \mathrm{NaCl}$ [21]. The probable reason of this insensitivity is the relatively strong hydrophobic interactions between histones and F-actin in addition to the strong electrostatic interactions between the constituents. There are also significant differences in the ionic strength sensitivity of F-actin bundled by the various histones, as $\mathrm{H} 2 \mathrm{~A}$ and $\mathrm{H} 2 \mathrm{~B}$ histone bundled F-actin almost completely dissociates by $300 \mathrm{mM} \mathrm{NaCl}$, while $\mathrm{H} 1, \mathrm{H} 4$ and 
H3.1 bundled actin filaments disassemble less than 50 percent even in the presence of $400 \mathrm{mM} \mathrm{NaCl}$. Since the number of the positive charges in the various histones, except H1 histone, are not significantly different (Table 1), the finding that $\mathrm{F}$-actin bundled by $\mathrm{H} 3.1$ and $\mathrm{H} 4$ histones are less sensitive to ionic strength than $\mathrm{H} 2 \mathrm{~A}$ and $\mathrm{H} 2 \mathrm{~B}$ histones indicates that the hydrophobic interactions between the H3.1 and $\mathrm{H} 4$ and $\mathrm{F}$-actin are stronger than between F-actin and $\mathrm{H} 2 \mathrm{~A}$ and $\mathrm{H} 2 \mathrm{~B}$ histones. As the number positive charges in $\mathrm{H} 1$ is significantly higher than in the other histones it is possible that to the relatively low ionic strength sensitivity of $\mathrm{H} 1$ is the results of both the higher electrostatic and hydrophobic interactions of this histone than the other extracellular histones with the actin filaments.

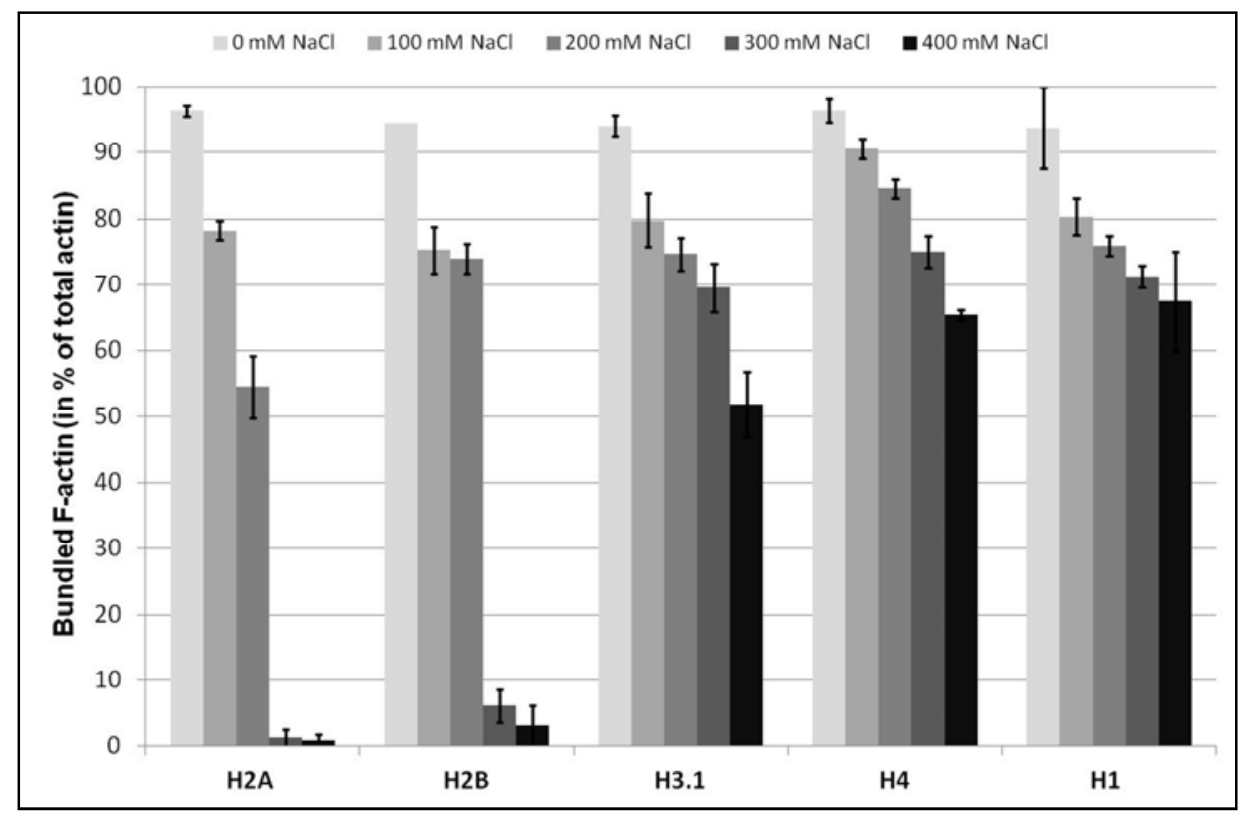

Figure 4. Dissociation of histones bundled actin filaments by increasing ionic strength. To 4uM F-actin bundled by 3.5uM histones $100-400$ mM NaCl was added. The bundled F-actin was separated from the unbundled one by low speed centrifugation and the supernatant was analyzed by SDS-Page as described in Materials and Methods. The presented data are mean and standard deviation of three independent experiments. $(p<0.1)$

DNA was shown to dissociate histone [14] and histone derivative (buforin) [24] bundled F-actin, because the strongly negatively charged DNA competes for the positively charged histones with the negatively charged F-actin. We studied the effect of DNA on the H2A, H2B, H3.1, H4 and
H1 histone induced F-actin bundles with low speed centrifugation (Figure 5), as the histone-DNA complexes, unlike the histone- F-actin complexes, are not sedimented with low speed centrifugation.

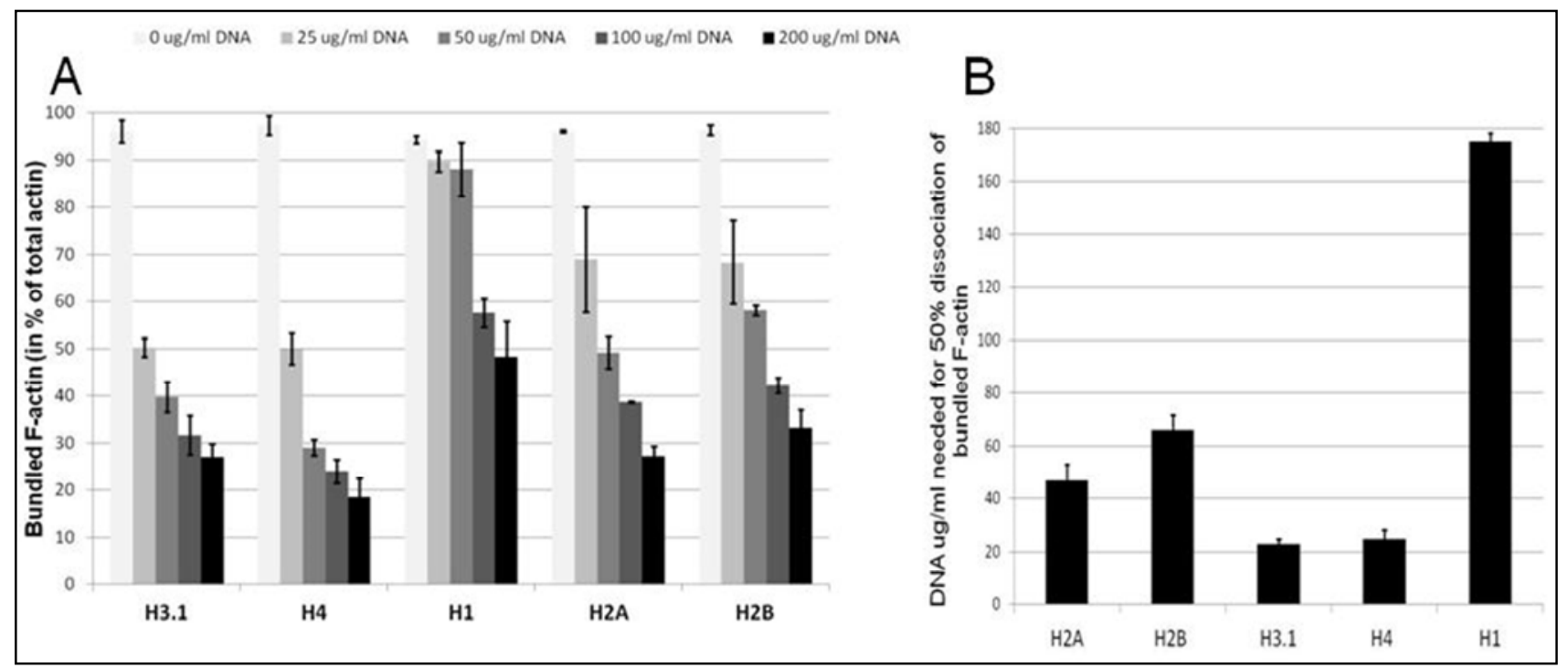

Figure 5. Dissociation of histones bundled actin filaments by DNA. (A), To 4 uM F-actin bundled by 3.5 uM histones 25-200ug/ml DNA was added. The bundled F-actin was separated from the unbundled F-actin by low speed centrifugation and the supernatant was analyzed by SDS-Page as described in Materials and Methods. (B), Amount of DNA needed for $50 \%$ dissociation of the histones bundled F-actin was calculated from the results presented in Figure $5 A$. The presented data are mean and standard deviation of three independent experiments. ( $p<0.05$ for $5 \mathrm{~A}$ andB) 
F-actins bundled by all histones used in this study were dissociated in different extent by DNA (Figure 5). The extent of dissociation depended on the extracellular histone used for the treatment. H1 histone bundled F-actin dissociated significantly only upon addition $100 \mathrm{ug} / \mathrm{ml} \mathrm{DNA}$, while the same degree of dissociation was obtained with $\mathrm{H} 3.1$ and $\mathrm{H} 4$ bundled F-actin by $25 \mathrm{ug} / \mathrm{ml}$ DNA. The concentration of DNA needed for 50 percent dissociation of the different histones bundled F-actin (Figure 5B) is a good measure to compare the binding strength between the individual histones and F-actin, The higher concentration of DNA is needed for dissociation the stronger is the binding between the specific histone and F-actin. The DNA needed for $50 \%$ dissociation decreased in the order $\mathrm{H} 1>\mathrm{H} 2 \mathrm{~B}>\mathrm{H} 2 \mathrm{~A}>\mathrm{H} 4>\mathrm{H} 3.1$. This well correlates with the extent of bundling caused by $1 \mathrm{uM}$ concentration of various histones (Figure 3B), since it decreases in the same order as the amount of DNA necessary for $50 \%$ unbundling. It should be also noted that the results in both Figures $5 \mathrm{~B}$ and $3 \mathrm{~B}$ are in the same decreasing order as the decrease of net positive charges of histones with the exception of H3.1 histone, which has more net positive charges than $\mathrm{H} 4$ and $\mathrm{H} 2 \mathrm{~A}$ (Table 1). All these findings indicate that mainly the strength of electrostatic interactions determine the strength of binding between the histones and F-actin. However, the macromolecular structure of bundled F-actin induced by the various histones may have also a role in the binding to F-actin, as it is indicated by the stronger dissociating effect of DNA on H3.1 induced F-actin bundles than would be expected from the number of positive charges in this histone.

DNase 1 is a G-actin binding protein. It binds very tightly to the D-loop of G-actin and forms co-crystals with actin monomers [24] and depolymerizes F-actin by binding to the protomer at the filaments ends. DNase 1 depolymerizes Factin filaments to $\mathrm{G}$-actin by dissociating actin monomers from the end of the filaments [25]. It efficiently unbundles LL-37 induced F-actin bundles [27, 28] and F-actin bundled by histone mixture and $\mathrm{H} 2 \mathrm{~A}$ histone [14]. We studied the DNase1 dissociation of F-actin bundles induced by five extracellular histones also with low speed centrifugation.

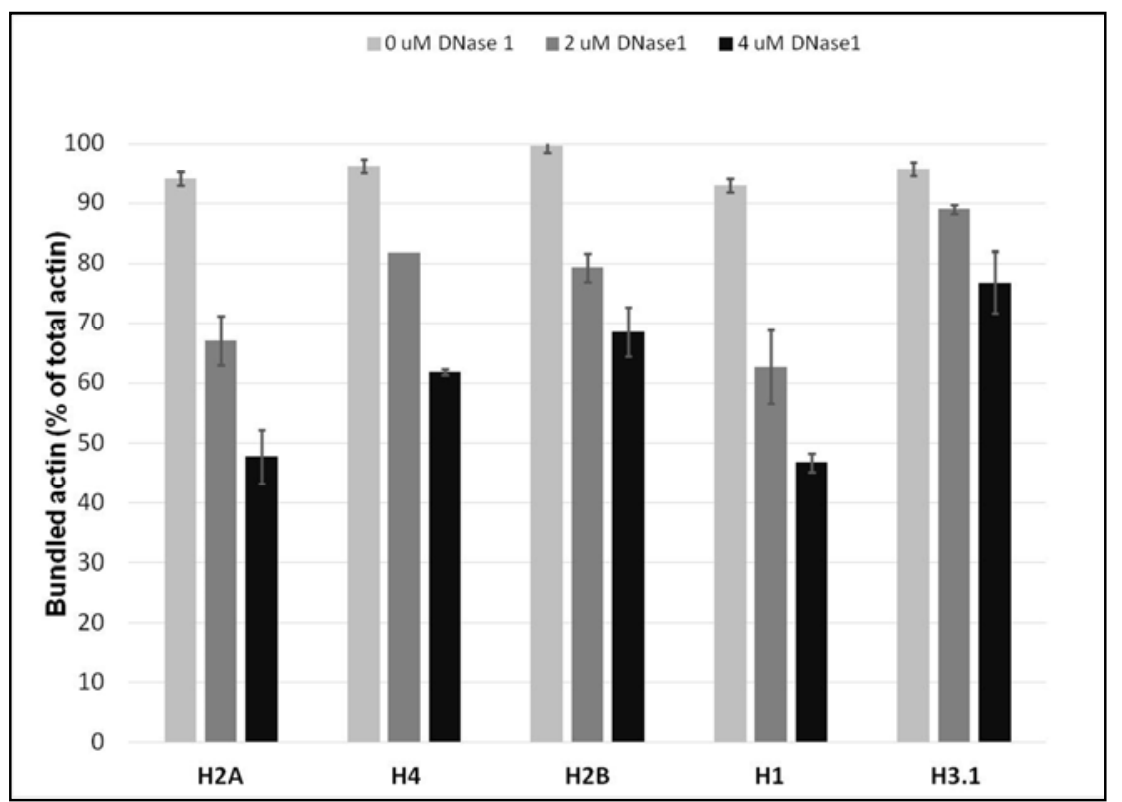

Figure 6. DNase1 induced dissociation of actin filaments bundled by DNA. To 4 uM F-actin bundled by 3.5 uM histones 0 , 2 or 4 uM DNase1 was added. Following 10 min incubation at $20{ }^{\circ} \mathrm{C}$ bundled F-actin was separated from the unbundled F-actin by low speed centrifugation and the supernatant was analyzed by SDS-Page as described in Materials and Methods. The presented data are mean and standard deviation of three independent experiments. ( $p<0.1)$

F-actin bundled by the five histones was found to dissociate in various extent upon addition of DNase1. The degree of unbundling increased with the concentration of DNase1 applied (Figure 6) and depended on the histone used. The extent of disassembly caused by $4 \mathrm{uM}$ DNase 1 decreased in the following order $\mathrm{H} 2 \mathrm{~A}=\mathrm{H} 1>\mathrm{H} 4>\mathrm{H} 2 \mathrm{~B}>\mathrm{H} 3.1$. The degree of dissociation reflects to the binding strength of DNase1 to the actin monomers at the end of the actin filaments [25] bundled by the different histones. The differences in DNase1 induced unbundling indicates that the macromolecular structure of actin filaments bundled by the various histones is different.

\subsection{Digestion of Histones by Bacterial Proteases and the Effect of DNA and F-actin on the Digestion}

Bacteria protect themselves against the antimicrobial activity of host defense proteins and peptides like extracellular histones using proteases, which degrade these protein-based immune factors. Extracellular histone mixture, which has strong antimicrobial action, has been shown to be efficiently digested by the proteases of Pseudomonas aeruginosa and Pseudomonas gingivalis pathogenic bacteria [12]. Here we studied the digestion of five extracellular histones by $\mathrm{P}$. aeruginosa, fusolisin and subtilisin bacterial proteases (Figure 7). 


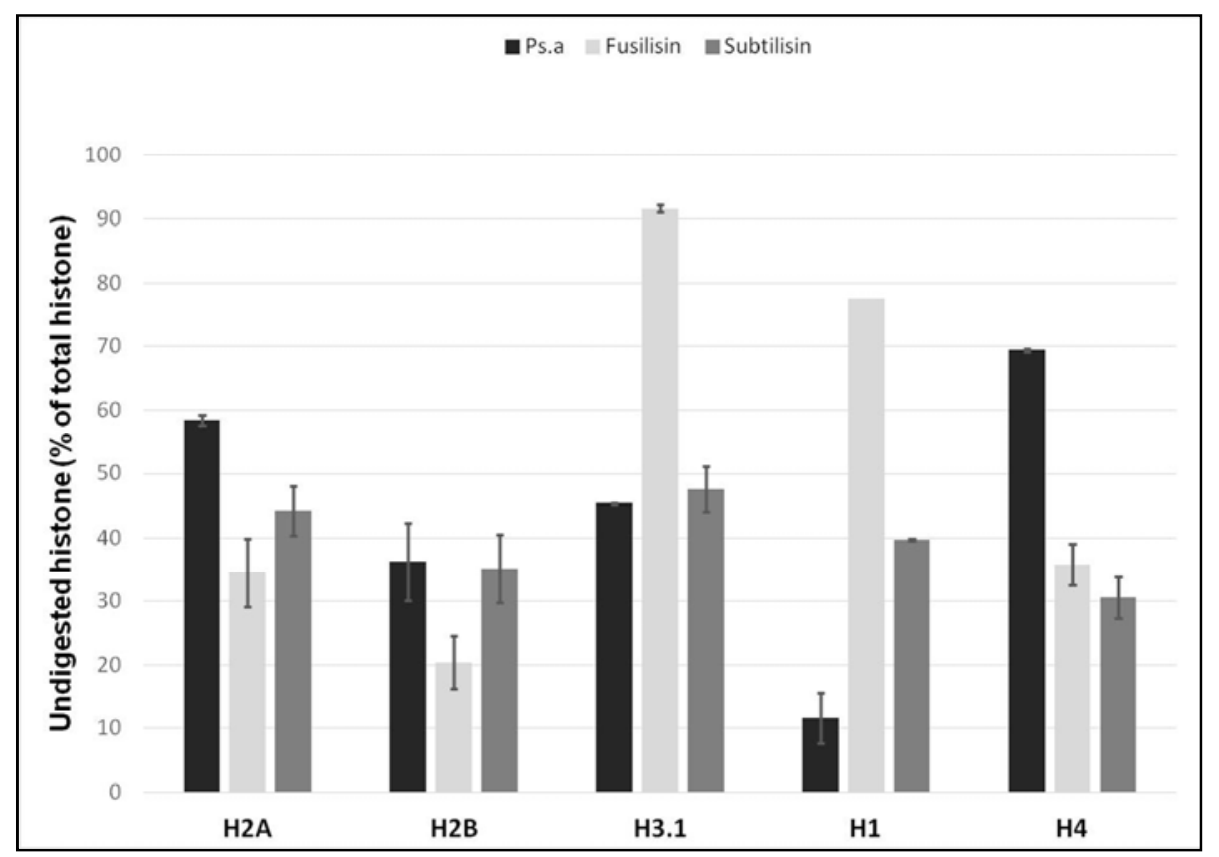

Figure 7. Digestion of extracellular histones by P. aeruginosa, fusolisin and subtilisin proteases. 3.5 uM histones were digested with (a) 50x diluted P. aeruginosa supernatant for $30 \mathrm{~min}$ at $20^{\circ} \mathrm{C}$ and the digestion was stopped by incubation in $100^{\circ} \mathrm{C}$ waterbath for $10 \mathrm{~min}$; (b) $8.5 \mathrm{ug} / \mathrm{ml}$ fusolisin for $150 \mathrm{~min}$ at $37^{\circ} \mathrm{C}$ and the digestion was stopped stopped by incubation in $100^{\circ} \mathrm{C}$ waterbath for $10 \mathrm{~min}$; (c) $2.5 \mathrm{ug} / \mathrm{ml}$ subtilisin for 10 min at $20^{\circ} \mathrm{C}$ and the digestion was stopped with $2 \mathrm{mM}$ PMSF. The digests were analyzed by SDS-Page and evaluated by densitometry as described in Materials and Methods. The presented data are mean and standard deviation of three independent experiment. $(p<0.005)$

All the three bacterial proteases found to digest the five extracellular histones but the various histones were digested in different extent by the three proteases. H1 histone was very sensitive to digestion by $\mathrm{P}$. aeruginosa protease, $\mathrm{H} 2 \mathrm{~B}$ and $\mathrm{H} 3.1$ were significantly less sensitive, while $\mathrm{H} 2 \mathrm{~A}$ and $\mathrm{H} 4$ in this order, were the most resistant. On the other hand by the fusolisin digestion $\mathrm{H} 3.1$ and $\mathrm{H} 1$ histones were the most resistant, as $\mathrm{H} 3.1$ and $\mathrm{H} 1$ remained 96.1 and 77.4 percent undigested respectively, $\mathrm{H} 4$ and $\mathrm{H} 2 \mathrm{~A}$ were significantly less resistant and $\mathrm{H} 2 \mathrm{~B}$ was the most sensitive, only 20.4 percent remained undigested, for the digestion. The differences in the extent of the subtilisin digestion for the various extracellular histones were much less significant. The differences in the digestion of the five histones are reflected to the specificity of the proteases and the different amino acid sequence of the histones and the differences also indicate that the secondary structure of the various histones is different.

The effect of DNA and F-actin on the digestion of histones by the three bacterial proteases was studied. Both DNA and F-actin inhibited the proteolysis but different extent. The digestion of all histones with $\mathrm{P}$. aeruginosa protease was inhibited by both DNA (Figure 8A) and F-actin (Figure 8B), however, differences were found in the inhibitory effect of DNA and actin on the digestion of individual extracellular histones.

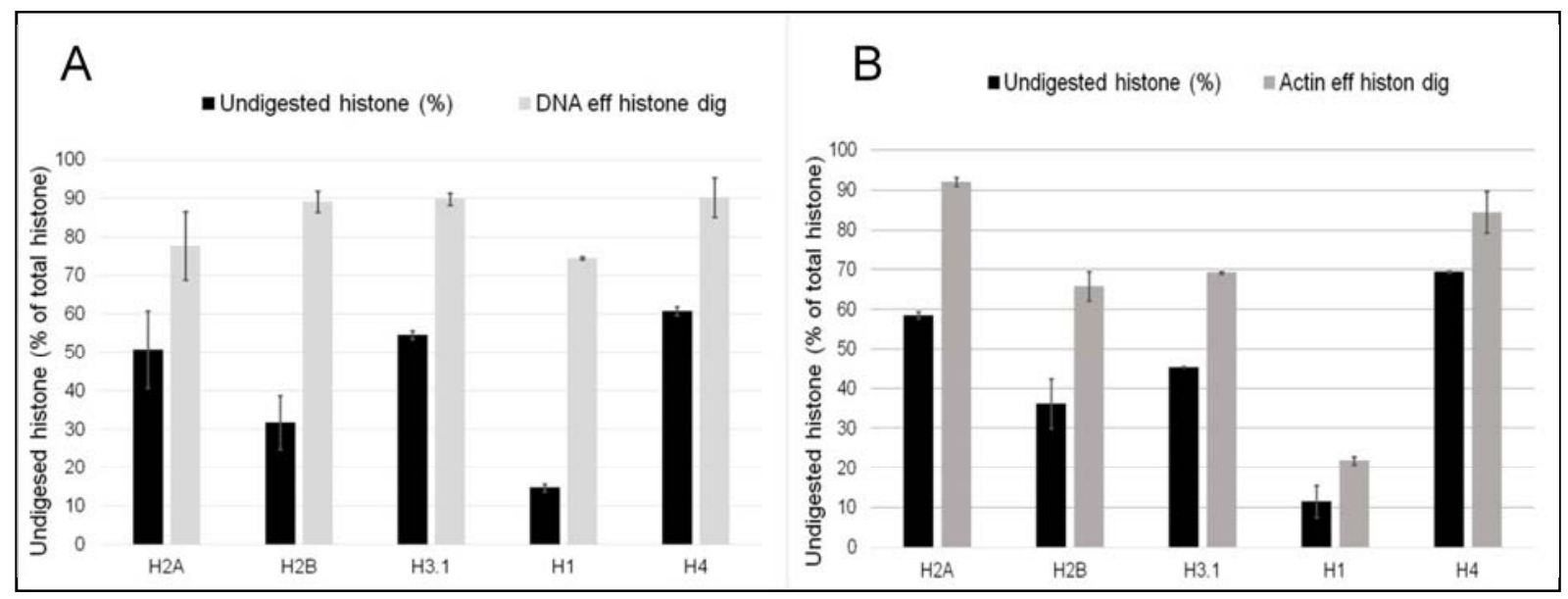

Figure 8. Effect of DNA and F-actin on the digestion of extracellular histones by P. aeruginosa protease. 3.5 uM histones were digested with 50x diluted P. aeruginosa supernatant with or without the presence of (A) $50 \mathrm{ug} / \mathrm{ml} D N A$ or (B) $8 \mathrm{uM} \mathrm{F-actin}$ 
For $30 \mathrm{~min}$ at $20^{\circ} \mathrm{C}$ and the digestion was stopped by incubation in a $100^{\circ} \mathrm{C}$ waterbath for $10 \mathrm{~min}$. The digests were analyzed by SDS-Page and evaluated by densitometry as described in Materials and Methods. The presented data are mean and standard deviation of three independent experiments. $(p<0.005$ for $8 \mathrm{~A}$ and $\mathrm{p}<0.01$ for $8 \mathrm{~B}$ )

The protective effect of DNA on $\mathrm{P}$. aeruginosa protease digestion of histones was very strong (Figure 8A). The amount of undigested $\mathrm{H} 1$ histone at the end of the digestion in the absence of DNA was 14.8 while in the presence of DNA 74.4 percent of the total histone, which is five times more than the amount of the undigested histone in the absence of DNA. From H2B, H3.1 and H4 histones in the presence of DNA about 90 percent and from H2A histone almost 80 remained undigested after the digestion with $\mathrm{P}$. aeruginosa protease. The protection of extracellular histones against P. aeruginosa protease digestion by F-actin (Figure $8 \mathrm{~B}$ ) was also good but showed a different picture than the protection with DNA. Here the protection of $\mathrm{H} 1$ histone was the smallest, 12 percent in the absence and only 22 percent undigested histone were found in the presence of F-actin. The largest amount histone remained undigested in the presence of F-actin from H2A histone, 92 percent, which was followed by H4 histone, 84 percent, H3.1 histone 69 percent and finally $\mathrm{H} 2 \mathrm{~B}$ histone 65 percent undigested at the end of digestion.

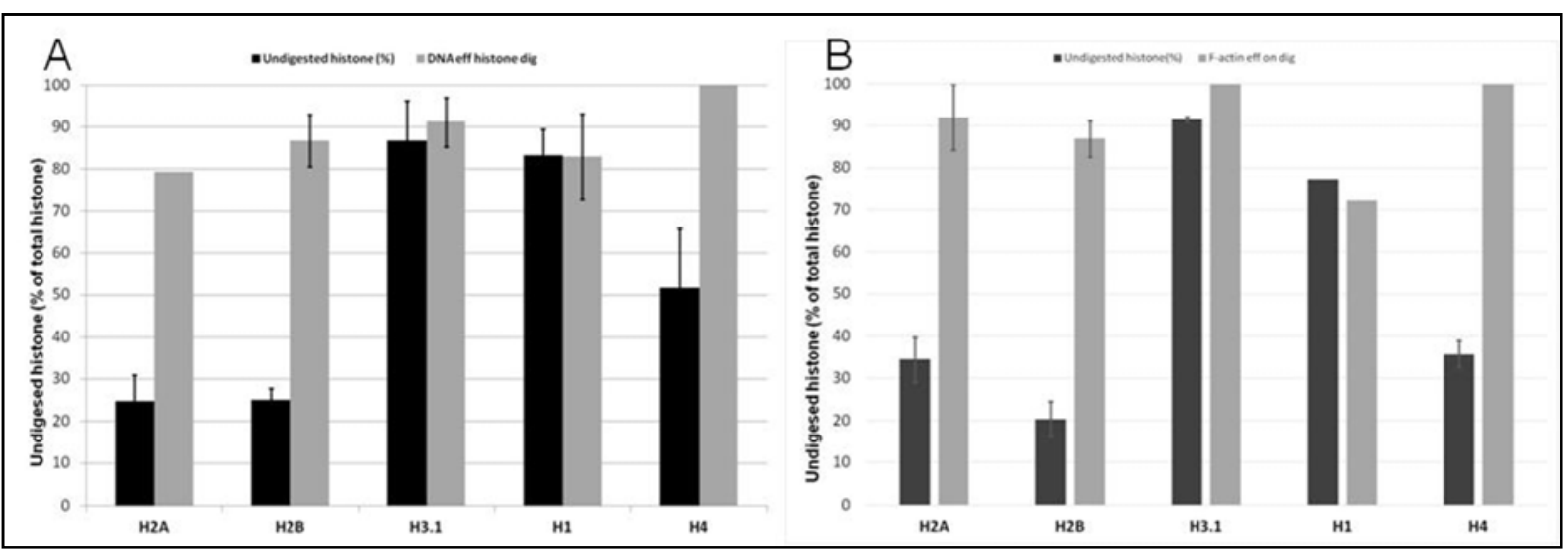

Figure 9. Effect of DNA and F-actin on the digestion of extracellular histones by fusolisin protease. 3.5 uM histones were digested 8 ug/ml fusolisin protease for 150 minutes at $37^{\circ} \mathrm{C}$ with or without the presence of (A) $50 \mathrm{ug} / \mathrm{ml} D N A$ or (B) $8 \mathrm{uM} \mathrm{F-actin} \mathrm{and} \mathrm{the} \mathrm{digestion} \mathrm{was} \mathrm{stopped} \mathrm{by} \mathrm{incubation} \mathrm{in} \mathrm{a} 100^{\circ} \mathrm{C}$ waterbath for $10 \mathrm{~min}$. The digests were analyzed by SDS-Page and evaluated by densitometry as described in Materials and Methods. The presented data are mean and standard deviation of three independent experiments. ( $p<0.01$ for $9 \mathrm{~A}$ and $P<0.005$ for $9 B$ ).

The effect of DNA (Figure 9A) and F-actin (Figure9 B) on the fusolisin digestion of histones showed great variations with the different extracellular histones. Those histones which are hardly digested with fusolisin, like H3.1 and H1, were almost not affected by DNA or F-actin, on the other hand on the digestion of $\mathrm{H} 2 \mathrm{~A}, \mathrm{H} 2 \mathrm{~B}$ and $\mathrm{H} 4$ both DNA and Factin have a strong protective effect. The amount of undigested histone in the present of DNA increased from
24.5 to 79.4 , from 25.1 to 86.8 , from 51.7 to 100 percent with $\mathrm{H} 2 \mathrm{~A}, \mathrm{H} 2 \mathrm{~B}$ and $\mathrm{H} 4$ histones, respectively. The presence of Factin during the digestion increased the amount of undigested histones from 20.4 to 86.9 , from 34.4 to 92.2 , from 35.8 to 100 percent with $\mathrm{H} 2 \mathrm{~B}, \mathrm{H} 2 \mathrm{~A}$ and $\mathrm{H} 4$ histones, respectively. The fusolisin digestion of all extracellular histones studied were similarly affected by both DNA and F-actin.

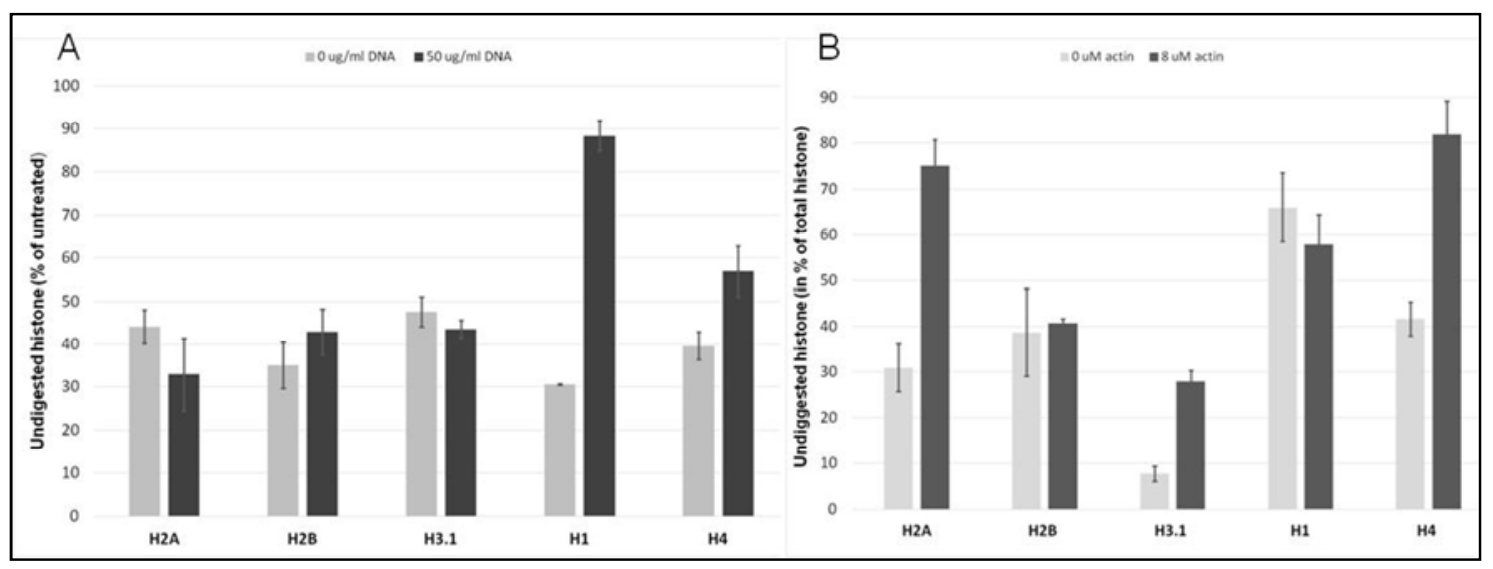

Figure 10. Effect of DNA and F-actin on the digestion of extracellular histones by subtilisin. 3.5 uM histones were digested with 2.5 ug/ml subtilisin for 10 min at $20^{\circ} \mathrm{C}$ with or without the presence of (A) $50 \mathrm{ug} / \mathrm{ml} \mathrm{DNA}$ or (B) $8 \mathrm{uM} \mathrm{F-actin} \mathrm{and} \mathrm{the} \mathrm{digestion} \mathrm{was} \mathrm{stopped} \mathrm{by} 2 \mathrm{mM} P M S F$. The digests were analyzed by SDS-Page and evaluated by densitometry as described in Materials and Methods. The presented data are mean and standard deviation of three independent experiments. $(p<0.1$ For $A$ and $B)$. 
Subtilisin is a wide specificity serine bacterial protease originally isolated from Bacillus subtilis which efficiently digests all extracellular histones studied (Figure 7). DNA has only a minimal effect on the subtilisin digestion of extracellular H2A, H2B and H3.1 histones but powerfully protects $\mathrm{H} 1$ and somewhat less efficiently $\mathrm{H} 4$ histones from the digestion, in the absence of DNA 30.6 and 39.7 percent while in its presence 88.4 and 57 percent undigested histone were found at the end of digestion, respectively (Figure 10A). F-actin differently affects subtilisin digestion of extracellular histones as DNA. It has a more protecting effect against subtilisin digestion of $\mathrm{H} 2 \mathrm{~A}, \mathrm{H} 3.1$ and $\mathrm{H} 4$ histones than DNA. Presence of $8 \mathrm{uM} \mathrm{F-actin} \mathrm{during} \mathrm{the} \mathrm{digestion}$ increased the percent of undigested $\mathrm{H} 2 \mathrm{~A}, \mathrm{H} 3.1$ and $\mathrm{H} 4$ histones from 30.9 to 75 , from 7.65 to 27.9 and from 41.7 to 81.9 percent, respectively (Figure 10B). The presence of Factin with $\mathrm{H} 2 \mathrm{~B}$ and $\mathrm{H} 1$ histones did not affect the extent of digestion. The finding that F-actin, which has less negative charge than DNA, protects more some extracellular histones from digestion than DNA points to the possibility that in this case the protection is not based on electrostatic interactions but more on structural changes which taking place in histones upon their binding to the DNA or F-actin macromolecules.

\section{Discussion}

All the recombinant histones studied here, $\mathrm{H} 2 \mathrm{~A}, \mathrm{H} 2 \mathrm{~b}$, H3.1, H4 and H1 histones, are bound to DNA. These histones were found to bind tightly to negatively charged DNA because of their high positive charge (Figure 1). These recombinant histones are identical with extracellular histones, which are released from the cell nucleus and became extracellular as a result of apoptosis $[2,3]$, necrosis [4] and infection - induced cell death [5]. The binding strength of the various histones studied to DNA was different. $\mathrm{H} 1$ and $\mathrm{H} 2 \mathrm{~A}$ histones were bound most strongly while the binding of $\mathrm{H} 3.1, \mathrm{H} 2 \mathrm{~B}$ and $\mathrm{H} 4$ histones were found to bind somewhat less (Figure 1). The binding strength seems to be dependent partially on the number of positive charges in histone and partially on the effect of histone on the molecular structure of DNA. H1 has the highest positive charge, (Table 1) and binds most strongly to DNA. H2A does not have higher number of positive charges than the other four extracellular histones still it binds stronger to DNA than $\mathrm{H} 3.1, \mathrm{H} 2 \mathrm{~B}$, and H4. It seems that strong binding of $\mathrm{H} 2 \mathrm{~A}$ is based mainly on the change caused by this histone in the molecular structure of DNA.

The interactions of the five extracellular histones with actin filaments (F-actin) was also studied. F-actin is released from cells following cell death and apoptosis and becomes extracellular [27] Positively charged histones strongly bind to negatively charged F-actin in substoichiometric and stoichiometric concentrations relative to actin. The tight binding between F-actin and histones is mainly due to strong electrostatic interactions and additional hydrophobic interactions. We studied the binding of histones to F-actin by measuring the effect of histones on the viscosity of F-actin and by the histone induced F-actin bundling.

The viscosity of F-actin containing solutions were found to increase upon addition of all the five extracellular histones (Figure 2). The viscosity increase is due to changes in the molecular structure of F-actin upon histone binding and less to electrostatic interactions since the observed viscosity change seems to be independent from the number of positive charges of the histone. The observed viscosity increase was highest with $\mathrm{H} 3.1$, which has a medium number positive charges among histones studied (Table 1), followed by H4 and $\mathrm{H} 1$ histones, this latter has the highest number of positive charges, and the smallest increase was found with $\mathrm{H} 2 \mathrm{~A}$ and $\mathrm{H} 2 \mathrm{~B}$ histones. The results indicate that the binding of various extracellular histones may cause different structural changes in the molecular structure of F-actin.

The highly positively charged extracellular histones like other polycations [21] bundle F-actin filaments because their high positive charge eliminates the repulsion between negatively charged actin filaments [20]. We found that histones are very efficient bundling agents and induce bundling already in substoichiometric concentrations relative to actin in much lower concentrations that other polycations, as polylysine, spermine and lysozyme [21] and histatin [23]. A good correlation was found between the number of positive charges in histones and the extent of bundling of Factin (Figure 3) with the exception of histone H3.1, which indicates that beside the number of positive charges other factors, like hydrophobic interactions or changes in molecular structure of actin also have a role in histone induced $\mathrm{F}$-actin bundling.

The effect of various factors, ionic strength, DNA and DNase1, which were shown to disassembly polycation induced F-actin bundles [14, 21, 23, 28] were studied here on extracellular histones induced F-actin bundles. High concentration of monovalent cations, like $\mathrm{NaCl}$, disassemble polycation induced F-actin bundles by neutralizing the repulsive negative charges of the $\mathrm{F}$-actin polyanion [22]. We found that at least $300 \mathrm{mM} \mathrm{NaCl}$ is needed to significantly unbundle $\mathrm{H} 2 \mathrm{~A}$ and $\mathrm{H} 2 \mathrm{~B}$ induced F-actin bundles while the $\mathrm{H} 3.1, \mathrm{H} 4$ and $\mathrm{H} 1$ induced bundle disassembly less degree even upon addition of $400 \mathrm{mM} \mathrm{NaCl}$ (Figure 4). The finding that much less $\mathrm{NaCl}$ is needed to disassemble $\mathrm{H} 2 \mathrm{~B}$ induced actin bundles than $\mathrm{H} 3.1$ and $\mathrm{H} 4$ induced bundles, inspite of $\mathrm{H} 2 \mathrm{~B}$ has significantly more net positive charges than the other two histones points to the possibility that $\mathrm{NaCl}$ in addition to weakening the electrostatic interactions may also affects the F-actin-histone hydrophobic interactions. The $\mathrm{NaCl}$ concentrations, which dissociate histone-F-actin bundles are much higher than those needed to unbundle lysozyme, polylysine and spermine [21] and histatin [23] induced actin bundles [21]. The high concentration of $\mathrm{NaCl}$ necessary to unbundle histone induced F-actin bundles together to the low concentration of histones needed to induces actin bundles (Figure 3 ) and the high viscosity of Factin in the presence of histones (Figure 2) indicates that the 
stability of F-actin-histone bundles is high.

Cystic fibrosis is the most common fatal inherited disease in the world [29]. The high stability and viscosity of the extracellular histones induced actin bundles have important pathological significance in cystic fibrosis. Actin bundles had been indicated to contribute the formation of the high viscosity sputum in cystic fibrosis [15]. Large quantities of Factin released as a consequence of the inflammatory cells lysis are shown to be present in the surface airway liquid [30]. Extracellular histones promoting the formation of stable F-actin bundles, were also found to be present in the bronchopulmonary secretions of patients with cystic fibrosis [31] and [32]. These stable histone-actin bundles increase the viscosity of sputum and aggravate the symptoms of cystic fibrosis patients.

DNA found to disassemble all the five extracellular histones induced F-actin bundles (Figure 5) similarly as it was shown earlier for histone mixture and $\mathrm{H} 2 \mathrm{~A}$ histone induced bundles [14]. The extent of unbundling seems to be mainly dependent on the number of net positive charges in histones as strong correlation was found between the decrease in the number of positive charges and the increasing dissociation of F-actin bundles (Figure 5A). These results indicate that the highly negatively charged DNA disassembles the histone induced F-actin bundles by competing with the negatively charged F-actin for the positively charged histones. The findings also support the conclusions of the results which showed that there is a correlation between the bundling of $\mathrm{F}$-actin and the number of positive charges of histones (Figure 3B), namely, that the strength of electrostatic interactions has an important role to determine the strength of binding between the histones and F-actin. The finding that H3.1 histone, which has more positive charges than $\mathrm{H} 2 \mathrm{~A}$ or $\mathrm{H} 4$ histones (Table 1) binds less strongly to F-actin (Figure 3) and more easily dissociates from F-actin by DNA (Figure 5) than H2A and $\mathrm{H} 4$ histones indicates that beside electrostatic interactions other factors also affect the binding strength between histones and F-actin.

It was found earlier that DNase 1 dissociates histone mixture, H2A histone [14] and LL-37 [27, 28] induced Factin bundles. Here we showed that all five extracellular histones induced $\mathrm{F}$-actin bundles are disassembled by DNase1 (Figure 6). DNase1 is known to bind strongly to actin monomers [25] and depolymerizes F-actin by binding to the monomer at the actin filament end, which causes the dissociation of this monomer from the filament. The extent of the DNase 1 caused F-actin bundle disassembly is different in the various extracellular histones induced F-actin bundles. It does not depend on the strength of electrostatic interactions between the histone and actin, since the degree of dissociation was the greatest with F-actin bundles induced by H1 histone, which has the highest number of net positive charge among the extracellular histones studied (Table 1). The reason of differences in the degree of DNase1 disassembly of the various histones induced F-actin bundles are seemed to be caused by the changes in the macromolecular structure of F-actin induced by the binding of different extracellular histones.

Extracellular histones have antimicrobial activity $[10,11$, 12], which has a positive physiological significance. Extracellular histones also have negative effects [33]. They may cause endothelial and renal dysfunction and found to be major mediators of sepsis induced death [34]. Extracellular histones can also play a significant role in tissue injury and inflammation [5]. Proteolysis of histones might have a balancing act between their positive and negative effects. We studied the proteolysis of extracellular histones by three bacterial proteases by subtilisin, Pseudomonas aeruginosa and fusolisin and the effect of DNA and F-actin on the digestions. All the extracellular histones studied were found to be digested by the three bacterial proteases (Figure 7) but different extent and the sensitivity of each histone to the various proteases used in this study also varied as it was detailed in the Results section.

DNA was found to strongly inhibit the digestion of histones by the three bacterial proteases. The inhibition was the most significant with $\mathrm{H} 1$ histone, which was hardly digested by the proteases when DNA was added. The percent of undigested $\mathrm{H} 1$ histone in the presence of DNA with $\mathrm{P}$. aeruginosa protease treatment (Figure $8 \mathrm{~A}$ ) was $75 \%$, with fusolisin $82 \%$ (Figure 9A) and subtilisin $89 \%$ (Figure 10A) of the total H1 histone present. Since H1 histone has the highest number positive charges of the five extracellular histones studied, the strong protective effect of negative charges rich DNA on $\mathrm{H} 1$ points to the significance of electrostatic interactions in histone-DNA binding. DNA protected also the degradation of $\mathrm{H} 2 \mathrm{~B}, \mathrm{H} 2 \mathrm{~A}, \mathrm{H} 3.1$ and $\mathrm{H} 4$ histones by $\mathrm{P}$. aeruginosa protease and fusolisin but not by subtilisin indicating that in this latter case the neutralization of the histones positive charges, except that of the positive charges of H1, does not inhibits the digestion.

F-actin quite differently protected the extracellular histones from digestion by the three bacterial proteases as that of DNA. H1 histone whose digestion by all the three proteases was strongly inhibited by DNA was slightly or not affected by the presence of F-actin. On the other hand the H2A histone whose digestion by subtilisin was not inhibited by DNA but strongly protected against subtilisin degradation by F-actin (Figure 10). Also the degradation of $\mathrm{H} 4$ and $\mathrm{H} 3.1$ histones by subtilisin was not or slightly affected by DNA but significantly protected by F-actin. All these results point again that the effect of DNA and F-actin on the molecular structure of histones is different. DNA affects mainly through its strong electrostatic interactions with histones [12], while F-actin through the strong attachment of histones to the bundled actin filaments. Both DNA and F-actin might induce different structural changes in the individual extracellular histones.

\section{Conclusions}

All the five extracellular histones studied were found to bind strongly to DNA and F-actin. The binding to DNA is mainly the result of electrostatic interactions between the 
highly negatively charged DNA and positively charged histone polycations, however, the structural changes caused by the binding of histones in the molecular structure of the DNA macromolecule may also have a role. Interaction of histones with F-actin induces bundling of actin filaments mainly by the effects of histones on the structure of the filaments through electrostatic interactions with the negatively charged F-actin. The histone induced bundling of F-actin has pathophysiological significance since actin bundles had been shown to contribute the formation of the high viscosity sputum in cystic fibrosis, which is a common fatal inherited disease.

\section{References}

[1] Tagai C, Morita S, Shiraishi T, Miyaji K, Iwamuro S. Antimicrobial properties of arginine- and lysine-rich histones and involvement of bacterial outer membrane protease $\mathrm{T}$ in their differential mode of actions. Peptides. 2011; 32: 2003 2009.

[2] Wu D, Ingram A, Lahti JH, Mazz B, Grenet J, Kapoor A, et al. Apoptotic release of histones from nucleosomes. J Biol Chem. 2002; 277: 12001-12008.

[3] Wickman GR, Julian L, Mardilovich K, Schumacher S, Munro $\mathrm{J}$, Rath $\mathrm{N}$, et al. Blebs produced by actin-myosin contraction during apoptosis release damage-associated molecular pattern proteins before secondary necrosis occurs. Cell Death Differ. 2013; 20: 1293-1305.

[4] Chen Kang R, Fan XG, Tang D. Release and activity of histone in diseases. Cell Death Dis. 20114; 5: e1370. doi: $10.1038 /$ cddis. 2014.337

[5] Allam R, Kumar SV, Darisipudi MN, Anders HJ. Extracellular histones in tissue injury and inflammation. J Mol Med. (Berl.) 2014; 92: 465-472.

[6] Sathyan N, Philip R, Chaithanya ER, Anil Kumar PR, Sanjeevan VN, Sing, ISB. (Characterization of histone H2A derived antimicrobial peptides, Harriottins, from Sicklefin Chimaera Neoharriotta pinnata (Schnakenbeck, 1931) and Its evolutionary divergence with respect to $\mathrm{CO} 1$ and histone H2A. ISRN. Mol Biol. 2013; 1-10.

[7] Robinette D, Wada S, Arroll T, Levy MG, Miller WL, Noga EJ. Antimicrobial activity in the skin of the channel catfish Ictalurus punctatus: characterization of broad-spectrum histone-like antimicrobial proteins. Cell Mol Life Sci. 1998; 54: 467-475.

[8] Lee HS, Park CB, Kim JM, Jang SA, Park IY, Kim MS, et al. (2008). Mechanism of anticancer activity of buforin IIb, a histone H2A-derived peptide. Cancer Lett. 2008; 271: 47-55.

[9] Richards RC, O’Neil DB, Thibault P, Ewart KV. Histone H1: an antimicrobial protein of Atlantic salmon (Salmo salar). Biochem Biophys Res Commun. 2001; 284: 549-555.

[10] Katchalski E, Bichovski-Slomnitzki L, Volcani BE. Action of some water-soluble poly-a-amino-acids on bacteria. Nature 1952; 169: 1095-1096.

[11] Hirsch JG. Bactericidal action of histone. J Exp Med. 1958; 108: $925-44$.
[12] Sol A., Skvirsky Y, Blotnick E, Bachrach G, and Muhlrad A. Actin and DNA protect histones from degradation by bacterial proteases but inhibit their antimicrobial activity. Front. Microbiol. 2016; 7: 1248.

[13] Ginsburg I, Mitra RS, Gibbs DF, Varani J, Kohen R. Killing of endothelial cells and release of arachidonic acid. Synergistic effects among hydrogen peroxide, membranedamaging agents, cationic substances, and proteinases and their modulation by inhibitors. Inflammation. 1993; 17: 295319 .

[14] Blotnick E, Sol A, Muhlrad A. Histones bundle F-actin filaments and affect actin structure. Plos One. 2017; 12 (8): $\mathrm{e} 0183760$.

[15] Vasconcellos CA, Allen PG, Wahl ME, Draven JM, Janmey PA, Stossel TP. Reduction in viscosity of cystic fibrosis sputum in vitro by gelsolin. Science. 1994; 263: 969-7121.

[16] Spudich JA, and Watt S. The regulation of rabbit skeletal muscle contraction. Biochemical studies of the interaction of the tropomyosin-troponin complex with actin and the proteolytic fragments of myosin. J Biol Chem. 1971; 246: 4866-71.

[17] Doron L, Coppenhagen-Glazer S, Ibrahim Y, Eini A, Naor R, Rosen G, Bachrach G. Identification and Characterization of Fusolisin, the Fusobacterium nucleatum Autotransporter Serine Protease. Plos One. 2014; 9 (10): e111329.

[18] Uyterhoeven ET, Butler CH, Ko D, Elmore DE. Investigating the nucleic acid interactions and antimicrobial mechanism of buforin II. FEBS Lett. 2008; 582: 1715-18.

[19] Tse WC, Boger DL. A fluorescent intercalator displacement assay for establishing DNA binding selectivity and affinity. Acc Chem Res. 2004; 37: 61-9.

[20] Tang JX, Janmey PA. The polyelectrolyte nature of F-actin and the mechanism of actin bundle formation. J Biol Chem. 1996; 271: 8556-63.

[21] Muhlrad A, Grintsevich EE, Reisler E. Polycation induced actin bundles. Biophys Chem. 2011; 155: 45- 51.

[22] Tang JX, Ito T, Tao T, Traub P, Janmey PA. Opposite effects of electrostatics and steric exclusion on bundle formation by F-actin and other filamentous polyelectrolytes. Biochemistry. 1997; 36: 12600-7.

[23] Blotnick E, Sol A, Bachrach G, Muhlrad, A. Interactions of histatin-3 and histatin-5 with actin. BMC Biochemistry. 2017; 18: 3 .

[24] Beyth N, Blotnick-Rubin E, Houri-Haddad Y, Beyth S, Muhlrad. Buforin III Analogs Bind to DNA and Actin and Inhibit Bacterial Growth. Advances in Biochemistry. 2018; 6 (5): 39-46.

[25] Kabsch W, Mannherz HG, Suck D, Pai EF, Holmes KC. Atomic structure of the actin: DNase I complex. Nature. 1990; 347: 37-44.

[26] Mannherz HG, Leigh JB, Leberman $\mathrm{R}$ and Pfrang HA. Specific 1: 1 G-actin: DNase 1 complex formed by the action of DNase 1 on F-actin. FEBS Lett. 1975; 60: 34-8.

[27] Sol A, Blotnick E, Bachrach G, Muhlrad A. LL-37 induces polymerization and bundling of actin and affects actin structure. Plos One. 2012; 7: e50078 (2012). 
[28] Sol A, Skvirsky Y, Nashef R, Zelentsova K, Burstyn-Cohen T, Blotnick E., Muhlrad A, Bachrach G. Actin enables the antimicrobial action of LL-37 in the presence of microbial protease. J Biol Chem. 2014; 289: 22926-22941.

[29] Welsh MJ, Smith AE (1995) Cystic fibrosis. Sci Am. 1995; 273: $52-59$.

[30] Bucki R, Byfield FJ, Janmey PA. Release of the antimicrobial peptide LL-37 from DNA/F-actin bundles in cystic fibrosis sputum. Eur Respir J. 2007; 29: 624-32.

[31] Brogan TD, Ryley HC, Neale L, Yassa J. Soluble proteins of bronchopulmonary secretions from patients with cystic fibrosis, asthma, and bronchitis. Thorax. 1975; 30: 72-79.
[32] Jay X, Tang JX, Wen Q, Bennett A, Kim B, Sheils CA et al. Anionic poly (amino acid) $\mathrm{s}$ dissolve F-actin and DNA bundles, enhance DNase activity, and reduce the viscosity of cystic fibrosis sputum. Am J Physiol-Lung Cellular and Molecular Physiol. 2005; 289: L599-L605.

[33] Xu Z, Huang Y, Mao P, Zhang J, Li Y. Sepsis and ARDS: The Dark Side of Histones. Mediators Inflamm. 2015; 2015: 205054.

[34] Xu J, Zhang X, Pelayo R, Monestier M, Ammollo CT, Semeraro $\mathrm{F}$ et al. Extracellular histones are major mediators of death in sepsis. Nat Med. 2009; 15: 1318-21. 